\title{
EXTRUDER CSIGA VIZSGÁLATA
}

\section{INVESTIGATION OF AN EXTRUDER SCREW}

\author{
Kozma Ferenc ${ }^{1}$, Ráthy Istvánné ${ }^{2}$, Varga Ferenc ${ }^{1}$, Prokisch József ${ }^{3}$

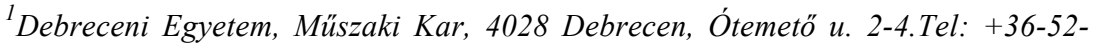 \\ 415-155,fg.kozma@gmail.com \\ ${ }^{2}$ Óbudai Egyetem, Bánki Donát Gépész és Biztonságtechnikai Mérnöki Kar, 1081 \\ Budapest, Népszinház u. 8. Tel.+36-1-666-5310, rathy.istvanne@bgk.uni-obuda.hu \\ ${ }^{3}$ Debreceni Egyetem, Temészettudományi és technológiai Kar, 4031 Debrecen, \\ Egyetem tér1.prokisch@eng.unideb.hu
}

\begin{abstract}
The extruder screw and cylinder of a special plastic polyethylene film processing machine has been renovated by a company. The screw reconstruction process involved the proper surface material removal and preparation of the screw, then replenishment of special wear-resistant material of $1.5 \mathrm{~mm}$ thickness, and finally finish machining fitted to the cylinder bore. Cylinder renovation process: increasing the cylinder bore diameter, forming the cylindrical surface of the bore by superfinishing. After machining the surface of the bore forming a special long-lasting wear-resistant layer by plasmanitriding. Quality reception place: the customer's premises, the machine was installed in operational state with a 72-hour trial run. During the trial run $16 \mathrm{~m} \times 0.15 \mathrm{~mm}, 16 \mathrm{~m} \times 0.17 \mathrm{~mm}$ and $12 \mathrm{~m} \times 0.2$ $\mathrm{mm}$ films were produced. After that errors were recorded. After further usage the screw stuck in the housing. Our aim was to determine the cause of errors, which were carried out by measurements and material tests.
\end{abstract}

Keywords: material investigation, extruder screw, wear-resistant layer

\section{Összefoglalás}

Polietilén fólia gyártását végző speciális müanyag feldolgozó gép extruder hengerét és csigáját újította fel egy cég. A csigafelújítás menete: a csigalevél palástfelület lemunkálása és megfelelő előkészítése után $1,5 \mathrm{~mm}$ rétegvastagságú speciális kopásálló anyaggal való feltöltés, majd a henger furatához illesztve készre munkálás. Hengerfelújítás menete: a henger furatát átmérő növeléssel, tükrös felületkiképzéssel hengeresre való megmunkálás. A megmunkálás után a furat felületén plazmanitridálással speciális, hosszú élettartamú kopásálló réteg biztosítása.” Minőségi átvétel helye: a megrendelő telephelye, gépbe beszerelt, üzemszerü állapotban, 72 órás próbaüzemmel. A próbaüzem során $16 \mathrm{~m}$ x 0,15 mm-es, $16 \mathrm{~m}$ x 0,17 mm-es és $12 \mathrm{~m}$ x 0,2 mm-es fóliák kerültek legyártásra. Ezt követően hibákat rögzítettek. További használatot követően a csiga beszorult a csigaházba. Cél a hibák okának meghatározása volt, melyet, mérésekkel, anyagvizsgálatokkal valósítottunk meg.

Kulcsszavak: anyagvizsgálat, extruder csiga, kopásálló réteg 


\section{Bevezetés}

Egy mủanyag fólia gyártásával foglalkozó cég megbízott egy múanyag feldolgozógépeket felújító és karbantartó céget, hogy az egyik fóliagyártó berendezésüket, ennek keretén belül az extruder csigát és hengert újítsa fel. A munka megtörtént, azonban a próbaüzem során a fólia vastagsága nem volt egyenletes, és a szürő tisztítása során túl sok volt a lekopott anyagszemcse. Rövid idejü használatot követöen a csiga beszorult a csigaházba. Ezen hibák okának felderítése volt a cél.

\section{Vizsgálatok}

\subsection{A berendezés múködésének leírása}

Az extruzió a polimer feldolgozás egyik leghatékonyabb, legjelentősebb technológiája, amelynek során a (tipikusan höre lágyuló) polimert az extruder képlékeny állapotba hozza, majd a viszkózus ömledéket homogenizálja, s ha kell, gáztalanítja, ezután nyomás alá helyezi (komprimálja), egy adott, változatlan keresztmetszetü, nyitott szerszámon keresztülsajtolja, a méretállandóságot biztosítva lehüti, $\mathrm{s}$ így állandó keresztmetszetủ polimerterméket gyárt tetszőleges hosszúságban, folytonos üzemben.[1]

Az eljárás egyik lényeges tulajdonsága, hogy a termék 3 dimenziós kiterjedése az egyik dimenzióban végtelen, ami lehet cső, síklap, profilos hasáb, fólia, stb. A feldolgozás utolsó fázisában mindig tekercselés vagy darabolás történik.

$\mathrm{Az}$ 1. ábrán egy fóia fúvó berendezés elvi elrendezése látható. $\mathrm{Az}$ alapanyagot por vagy granulátum formájában lehet beadni, amelybe adalék anyagokat szoktak belekeverni.

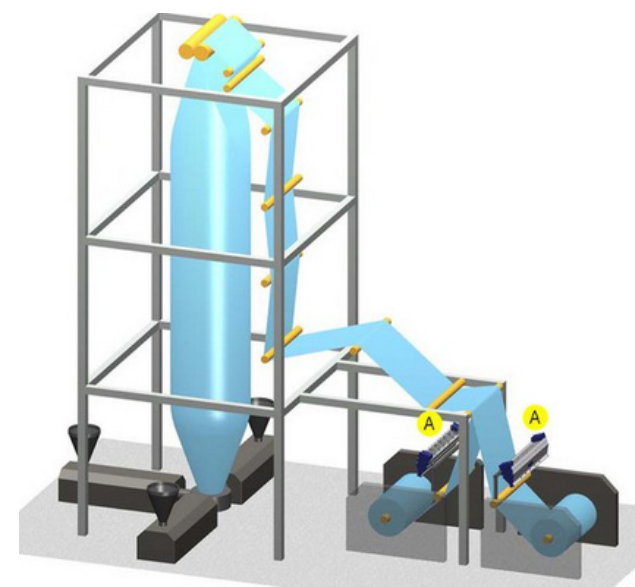

1. ábra. Fólia fúvó berendezés elvi elrendezése

Ilyen adalékok lehetnek a hőstabilizátorok, amelyek csökkentik a degradációs hajlamot, UV stabilizátorok, amelyek a természetes fény elleni védelmet biztosítják, lágyítók, amelyek a feldolgozást segítik elő, lángállóságot biztosító adalékok, csúsztató szerek, amelyek a csigasúrlódást csökkentik, stb.

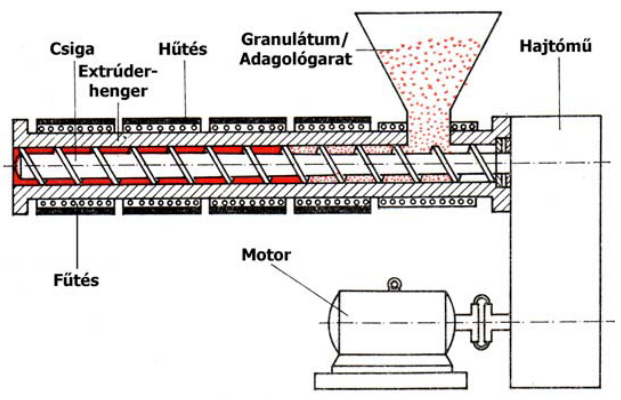

2. ábra. Az extruder felépitése

Az adalékokat (hideg, meleg) porkeverőkben adalékolják, a granulátumot pedig úgynevezett nagyteljesítményü granuláló-extruderben készítik. (Lásd 2. ábra) [2] 


\subsection{A felújítás technológiájának vizsgálata}

Az extruder használata során a csiga és a csigaház is megkopott. A kopás feltételezhetően a mủanyaggal való súrlódás miatt következett be. (A frikciós hőképződés jelentős súrlódást igényel a mủanyag és az azt szállító elemek fala között.)

A kopások következtében a csigaház belső hengeres felületének átmérője nőtt, a csigalevél külső hengeres felületének átmérője csökkent. Ezek a kopások nem egyenletesek, a felületek bizonyos részein nagyobbak, bizonyos részein kisebbek.

A fent leírt méretváltozások egy ideig nem voltak hatással a technológiai folyamatokra, de a csiga-csigaház résméretének növekedéséhez vezettek. Amikor ez már olyan mértéküvé fejlődött, hogy a gyártást zavarta, az elemeket fel kellett újítani. (pl. meghaladta a 0,005D értéket)

A felújítási technológiát úgy kellett megválasztani, hogy a csigaház belső hengeres felületét a lehető legkisebb méretnövekedéssel hengeresre alakítsák, ekkor azonban a rés megengedettől nagyobb mértékben megnőtt. Emiatt a csiga külső hengeres csavarfelületét fémpor felszórással feltöltötték. Ez a feltöltés nem adott megfelelö felületi érdességet, alakhüséget és méretpontosságot. Emiatt a csigalevél külső felületét meg kellett köszörülni. Mivel szokatlanul nagyméretű az extruder, a köszörülést egy egyetemes csúcsesztergán, szánköszörü készülékkel (szupportköszörü) végezték el. Az eszterga csúcstávolsága kisebb volt, mint a csiga hossza, emiatt két felfogásban, állóbábbal való megtámasztással köszörülték meg. A csigaház belső felületeinek nitridálását egy hőkezeléssel foglalkozó német cégnél végezték el. A csigaház furatának javítása honolással történt. A csigaház furatának szabályos hengeresre munkálása során annak átmérője nagyobb lett. A résméret megfelelő mértékü beállítása szükségessé tette a csigalevél külső átmérőjének növelését. Ezt a kialakult technológia szerint hideg fémporszórással szokás biztosítani. (Hideg eljárásoknak nevezzük azokat az eljárásokat, amelyeknél az alkalmazott munkadarab hömérséklete alacsonyabb, mint az adott anyagra jellemző újrakristályosodási hőmérséklet. Ez a csiga esetében $450-480{ }^{\circ} \mathrm{C}$ lehet.) A felszórt réteg jobb tapadása, nagyobb szilárdsága miatt az acél felületre egy alapozó réteget szórtak fel, melynek vastagsága a 3. ábrán $\mathrm{A}_{4}$, illetve $\mathrm{B}_{4}$-vel van jelölve, az általunk mért értékei a 1. táblázatban vannak megadva.

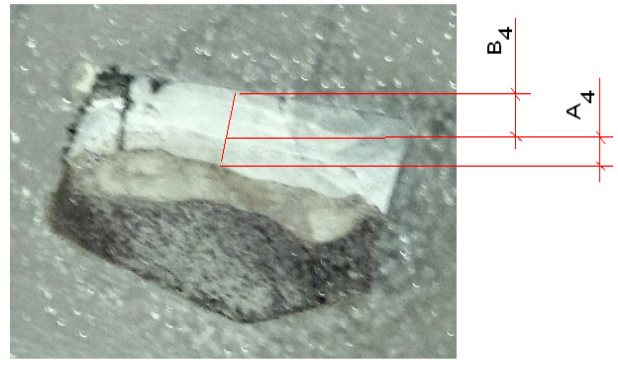

3. ábra. A felszórt réteg vastagsága

1. táblázat. A mért felszórt fémpor réteg vastagsága a csigalevélen

\begin{tabular}{|c|c|c|}
\hline $\begin{array}{c}\text { Réteg } \\
\text { megnevezése }\end{array}$ & Mérések & Átlag \\
\hline $\begin{array}{c}\text { Alapozó réteg } \\
\text { (A) }\end{array}$ & 1,$30 ; 1,45 ; 1,70$ & 1,49 \\
\hline Fedő réteg (B) & 2,$50 ; 2,40 ; 2,70$ & 2,54 \\
\hline
\end{tabular}

A számtani átlag elfogadható rétegvastagságként, bár az alapozóréteg és a fedőréteg is vastagabb a szokásosan alkalmazott fémporréteg vastagságtól. Ezt a csigaház-csiga páros nagyobb mértékü kopása indokolta. Másképp nem lehetett volna biztosítani a megfelelő résméretet. 


\subsection{Szövetszerkezeti vizsgálatok}

A csigaház felületéből, és a csigalevélből mintákat vettünk ki. Ezeket mügyantába beöntve síkba csiszoltuk, és a mikrocsiszolat készítésének szabályai szerint vizsgálati mintákat készítettünk.

A keménységmérést Mikro-Vickers módszerrel, a metallográfiai vizsgálatokat fémmikroszkóppal végeztük el. Egy-egy szövetképet a 4., és az 5. ábra mutat.

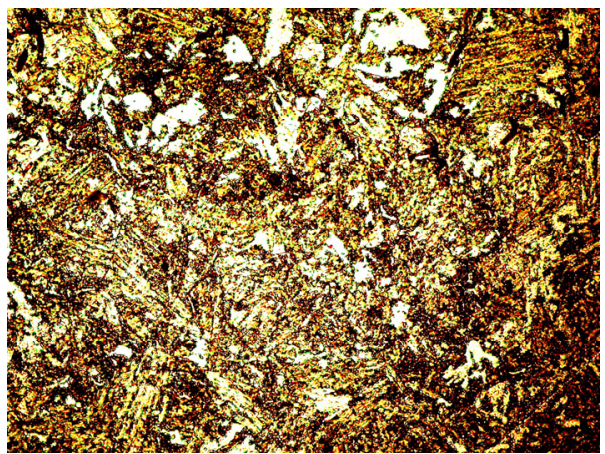

4. ábra. Csigalevél alapszövet (500x)

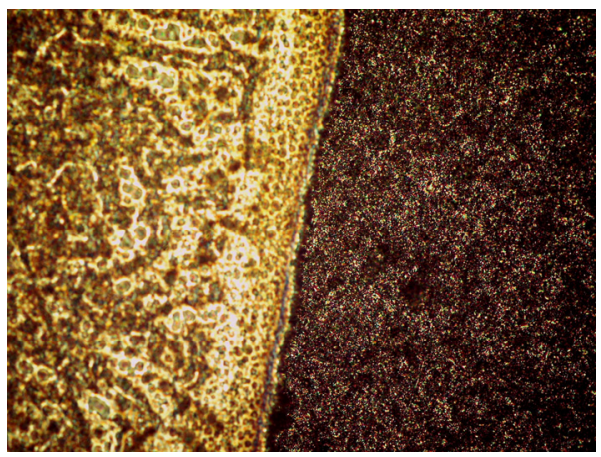

5. ábra. Csigalevél alapszövet és az 1. réteg átmenete (500x)

Mind a szövetszerkezeti vizsgálatok, mind a keménységmérések a szakmai szabályoknak megfelelő eredményt mutattak. A keménység értékeket a 2 . táblázat mutatja.
2. táblázat. A mért keménységek Vickersben

\begin{tabular}{|c|c|c|}
\hline Sorszám & Mérés helye & 4-es csigalevél \\
\hline 1. & Alapanyag & $250-260$ \\
\hline 2. & 1-es réteg & $420-450$ \\
\hline 3. & 2-es réteg & $570-600$ \\
\hline 4. & 3-as réteg & $760-800$ \\
\hline
\end{tabular}

\subsection{A csiga-csigaház méreteinek ellenőrzése}

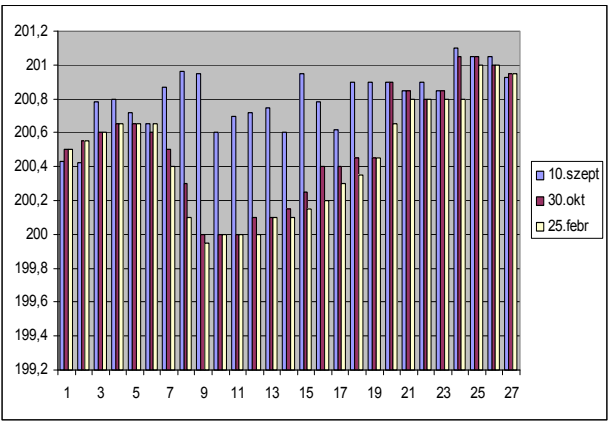

6. ábra. Csiga átmérö mért értékei

A csiga méretei 201,15mm és 199,88mm között változnak. (Lásd 6. ábra)

A csigaház esetében három értéket mértünk: 201,4; 201,1; 202,2 mm.

\section{Következtetések}

Az extruder megfelelö müködéséhez $0,4 \mathrm{~mm}$ résméret szükséges a csiga és a csigaház között sugárban értelmezve. Ez az érték sok helyen eltért, $0,18 \mathrm{~mm}$ és $1,2 \mathrm{~mm}$ között volt. Ez okozta a fóliavastagság nem megfelelőségét.

A csiga egyenességi alakhibája a lánghegesztő berendezéssel való melegítés során történhetett a szétszereléskor, ezt követően ezért szorult be.

\section{Szakirodalmi hivatkozások}

[1] Schaaf-Hahnemann: Müanyagok feldolgozása Müszaki Könyvkiadó Bp. 1997.

[2] Czvikovszky-Nagy-Gál: A polimertechnika alapjai. BME kiadó, Bp, 2007, 117-118 